\title{
Describing the past: \\ Tartu-Moscow School ideas on history, historiography, and the historian's craft
}

\author{
Taras Boyko \\ Department of Semiotics \\ Universty of Tartu \\ Jakobi 2, 51014 Tartu, Estonia \\ e-mail: taras.boyko@ut.ee
}

\begin{abstract}
The article provides a survey of some milestone works of representatives of the Tartu-Moscow School (Juri Lotman, Boris Uspensky and Vladimir Toporov) focused on the topic of history, approaches to the past, historiographical strategies, the essence of the historian's craft, etc. Although these topics associated with the problem of history for the most part remained marginal in the research agendas of the Tartu-Moscow School, still a number of scholars affiliated with the School voiced novel and interesting thoughts and proposals regarding history and the historian's craft, and to some extent even catalyzed new discussions and spotlighted previously disregarded research problems. The current article intends to give a brief overview of the most important and influential ideas on the topics found in the works of the Tartu-Moscow School scholars.
\end{abstract}

Keywords: Tartu-Moscow School, Lotman, Toporov, Uspensky, history, historiography, semiotics of history

...об истории нам больше могут поведать специалисты, историками, строго говоря, не являющиеся.

Aron Gurevich ${ }^{1}$

Culture is simultaneously complex and nuanced, as it remains a traditionally fascinating and challenging research object for academia. Never-ending disagreements powered by constant scholarly debates around 'culture' and culture-related issues (e.g. what is culture? how can we study it? what is the researcher's role in the study of culture?) serve to be the best proof of the dynamic nature of this research object. But no matter how varied and multilayered interpretations of culture may be, a number of the features of

1 Gurevich 2004:186 [Scholars who, strictly speaking, are not historians can tell us more about history. My translation, T.B.]. 
culture tend to be present in the majority of scholarly opinions when it comes to defining culture or explaining the essence of its constituents. One such issue seems to be that of historicity or, in other words, cultural change in relation to temporality. Depending on personal preferences and academic trends, historicity may be called progress, regress, development, or simply change. For the purposes of this paper, it makes sense just to stress the presence of a historical edge (the intersection of historiography, temporality and teleology) in any culture-related research, while the actual labelling of historicity can and should be a matter of a different story.

For any reader familiar with the works of the scholars usually known under the umbrella phrase "Tartu-Moscow School" it will not come as a surprise that culture in its totality of meanings and processes occurring in it would eventually become, ${ }^{3}$ and, for a long time, stay, a central topic of their academic inquiry. However, it should also be noted that the majority of the scholars who were, or at least were considered to be, part of the Tartu-Moscow School of Semiotics in terms of disciplinary identity belonged to the circles of philologists/literary scholars and/or had a connection with linguistics. Nevertheless, the practice of crossing disciplinary boundaries was rather widespread among members of the School. Scholarly interest in various cultural processes is likely to mean the tendency towards "broad" and universal approaches, as well as extension across the boundaries of any particular discipline.

For instance, in the Soviet context - and especially for an audiences coming from non-academic circles - the leader of the School Juri Lotman was known primarily as a historian of Russian culture and literature based on his various works which tended to describe and analyse 18-19th-century cultural life and literary tradition in the Russian Empire, e.g. the TV series Conversations about Russian Culture [Besedy o Russkoj Kul'ture] broadcasted in the late 1980s-early 1990s, etc. In this regard, Lotman definitely was not the only representative of the School in some way engaging in discussions associated with the "problem of history", historicity, or any general interconnections/interdependencies between culture and history. When reading late Lotman, it becomes especially clear that a variety of pitfalls accompanying historiographical practices - both on the levels of empirical research and theory - were of particular interest to the Tartu professor.

The intention of this article is to take a look at a number of ideas and discussions about history originating from or in some way associated with the members of the TartuMoscow School, and, in addition, to try to place these ideas and thoughts in the context of Soviet "historical science" ${ }^{\text {, }}$, as well as the Soviet historiographical tradition of the time.

2 On this topic, see also Boyko 2014.

3 Perhaps the most obvious example here would be Theses on the Semiotic Study of Cultures (1973) that is programmatic for the School.

4 Here the term "historical science" is the translation of the Russian "историческая наука". During the Soviet period it was fairly common and widely used by both humanities scholars 


\section{Vladimir Toporov}

A good starting point for this brief overview of the ideas of the Tartu-Moscow School could be Vladimir Toporov's article On cosmological sources of early historical descriptions [O kosmologicheskih istochnikah ranneistoricheskih opisanij, Toporov 1973]. The article nicely sets the stage for a discussion regarding the Tartu-Moscow School and the "problem of history", while being chronologically the earliest dated piece among the works considered in this overview.

In its opening part, Vladimir Toporov reserves a few pages to the discussion of rather general issues, that nevertheless could be described as having cornerstone value, which were bothersome to contemporary historiography and theory of history considering that the article was published in 1973. The main issue, or concern, for Toporov is the various challenges history as a humanitarian discipline is faced with, such as: what is the nature of history? what is the object of study of historical science? what type of facts and methods can serve as grounds of historical research? Addressing these challenging questions is an important detail in the history of ideas, especially considering the fact that immediately after voicing these sets of important questions the Moscow scholar tries to formulate, as he calls it, "certain provisions" (nekotorye pologeniya) regarding history which are indisputably justifiable in other semiotic systems: (1) "text" of historical description usually presents itself as a weave of several texts out of which historical text can and should be constructed; (2) the same element of historical description may carry different meanings (as well as the other way around - different elements can have the same meaning); (3) it is important to differentiate synchronic (from within the described state) and asynchronic descriptions (Toporov 1973: 109-110). Again, it should be stressed that Toporov wrote the article in the early 1970s, but it is possible to see how all three observations would be further developed, and partly also modified, by other members of the Tartu-Moscow School already in the next 10-15 years. In retrospect, this article can serve as an illustration of the state of thought among the members of the School, especially in terms of scholarly problems they were trying to tackle or preparing to address.

and ordinary readers when referring to the study of the past. The quotation marks emphasize the double irony (at least from the contemporary point of view) associated with the term: science (наука) in regards to history writing per se, and the particular type of scientificity of the Soviet form of historiographical scholarship. 


\section{Juri Lotman}

Speaking about Juri Lotman, one of the first milestones marking his interest in the issues of historiography, theory, and, in some sense, even philosophy of history could be associated with the publication of the article prepared by mathematicians Mikhail Postnikov and Anatolij Fomenko titled "New methods of statistical analysis of the narrative-numerical material of ancient history" ["Novye metodiki statisticheskogo analiza narrativno-tsifrovogo materiala drevney istorii" in Sign Systems Studies 15, 1982].

As an editor of the volume, Lotman was not impressed by the article's rather controversial content ${ }^{5}$. Thus, he included a short editorial note along with the piece, so-called "objections" to accompany the article by Postnikov and Fomenko (Lotman 1982: 44-48). The note is only a few pages in length, but at the same time it contains a number of important points which are relevant for anyone interested in how Lotman conceived of the nature of history and historiography, and understood it.

First, Lotman addresses crucial problems associated with any historical documents (by those he means historical sources). For the Tartu scholar these documents potentially have a varied semiotic nature, and in the long run such variability in itself greatly influences the so-called "distortion factor" (koeffitsient iskazheniya) of the overall picture portrayed in the document (Lotman 1982: 44). Next, Lotman continues by discussing "texts with a strong degree of mythologization" (teksty s sil'noy stepen'yu mifologizatsii). At this point he specifically points out the predisposition of such texts towards hyperbolization and idealization. Lotman considers these potential tendencies to hyperbolize and idealize to be rituals of text composition, which in his opinion are hardly taken into consideration in the context of any statistical analysis of a bulk of historical sources. ${ }^{6}$ By contrast, Lotman suggests that any statistics-oriented account should be preceded by semiotic analysis of each particular source (Lotman 1982: 44-45). Such analysis would presumably help to establish the overall level of distortion of the source at stake. So, basically we have here two major ideas coming from Lotman: the first idea regards varied semiotic nature of this or that source material and such consideration eventuates in certain interpretive nuances, whereas the second idea actualizes the importance of the potential textual and narrative devices present in historical sources, which again should catch a scholar's attention at the moment of interpretation.

Towards the late 1980s Lotman became even more interested in the set of issues and problems associated with history and historical writing(s). For instance, formal rise of interest in these topics can be marked by the founding of the famous Laboratory

5 For instance in a letter to Boris Uspensky Lotman writes: "Postnikov's article - nonsense! But we will print it [...]” [“...Статья Постникова - бред! Но печатать будем...”] (Lotman, 28 March 1980, my translation T.B.)

${ }_{6}$ Statistical analysis was the key argument behind the article of Postnikov and Fomenko. 
of History and Semiotics. In terms of written works many might remember one of his best-known books, at least to the "Western" reader - Universe of the Mind: A Semiotic Theory of Culture (Lotman 1990). In connection with this important work it is impossible not to mention Vyacheslav Ivanov's foreword to the Russian language edition of the same work (Vnutri myslyashchikh mirov. Chelovek-tekst-semiosfera-istoriya, Lotman 1996), where Ivanov noted that the problem of history was one of the main theoretical problems Lotman was concerned with during the last years of his life. In any case, "Cultural Memory, History and Semiotics", the third section of Universe of the Mind is a must-read for anyone interested in this period in the second half of the 1980s that was quite fruitful for Lotman.

Let us take a closer look at this book that was originally written ${ }^{8}$ in Russian during 1988-1989. It was published in English in 1990 and happened to be Lotman's first essential lengthy publication deliberately prepared for the Western audience. In the above-mentioned third section, starting from the very first page Lotman tackles a crucial scholarly issue - the problem of text. He is being rather straightforward here: for Lotman, historians are condemned to deal with texts, texts being a sort of intermediary agent between an event as it happened and a historian investigating this event. Besides being an intermediary, text also plays a role of the most biased element in the set of procedures associated with historians' investigative practices, mainly because a text is always "[...] created by somebody and for some purpose, an event appears in it in some encrypted way" (Lotman 1996: 301-302).

According to Lotman, for historians the outcome of such state of affairs is the fact that their starting point in case of any research, first of all, can be narrowed down to the need of dealing with potentially misrepresenting elements, and the necessity to decode this or that text - to some extent, even to create a fact, while trying to extract some extra-textual reality from the analysed text, and event from a story about this event (Lotman 1996: 301-302). Lotman's stress on concepts such as code, encode(r), decode(r) in connection with historians and their source materials became one of the cornerstones of his approach to the "problem of history". In a way, such terminological borrowing from semiotics allowed Lotman to juxtapose his understanding of history informed by semiotics of culture with the classic scheme of rather judgmental positivist text critique, which was a dominant technique of source analysis among professional historians, especially historians working within the realities of the Soviet "historical science".

Based on such an understanding of the situation in historiography, Lotman proposed to pay more attention to reconstructing the set of codes used by the author (chronicler,

Память культуры. История и семиотика.

8 Some parts of it were also collected and re-written works from the older times.

9 [“....кем-то и с какой-то целью создан, событие предстает в нем в зашифрованном виде”] 
ancient historian, etc.) of the source text studied, while at the same time correlating it with the codes used here and now, meaning codes of the particular historian or perhaps even an ordinary reader. Basically, the goal is to find out what was considered to be a fact by the author of this or that analysed text, and only afterward make any attempts to establish fact(s) "for yourself" - a sort of ground zero for outlining the range of the potential interpretations of this fact (Lotman 1996: 302-303).

Further in the same section of the book, Lotman turns to another important issue he points out the inevitable structural unity brought along with the narrativization of events. Such unity organizes material in a system of temporal and causal coordinates. What seems to be evident for Lotman is the presence of rhetorical and ideological levels which accompany a variety of narrative structures. Thus genre-based, ideological, political, social, religious, philosophical, and other codes should necessarily be taken into consideration as unavoidable elements of any narrative-based sources (Lotman 1996: 310).

At first glance, these ideas do not look revolutionary or unexpected for historiography (or the humanities in general) of the 1980s-early 1990s. However, it is important not to disregard the Soviet factor here, mainly because of the fact that disciplinary history developed in a very particular way in the USSR. Being a historian (for the most part a rather conservative profession to begin with) meant following a certain predefined line of thought, while any steps to the side were a rather risky scholarly path to take. "Correct treatment" of the past, including theory of historical processes and philosophy of history, was a quintessential element of the scholarly activity. As an indirect outcome, most of the institutionalized historians "turned a blind eye" to any type of debates on the shaky ground of the philosophy of history, or any discussions about the essence of historical writing, historiographical strategies and questions alike. At the same time, a multitude of Western scholarly "revolutions" (e.g. the highly influential "linguistic/narrative turn") did not reach the minds of the absolute majority of Soviet professional historians for obvious reasons. In light of a such state of affairs in Soviet historiography ${ }^{10}$, what is most important is that with help from Lotman, developments in cultural semiotics (at least in the Tartu-Moscow School form) were transferred to, and partly even applied in, the realm of historiography.

At the same time, Lotman should not be portrayed as a radical academic revolutionary. Let us remember Mikhail Gasparov's well-known article "Lotman and Marxism" (Gasparov 1996), in which he noted among many interesting comments that in his work Lotman thoroughly followed the principles of dialectics and historism. Many of Lotman's ideas regarding history described above can certainly bear the label of historism, maybe even not in a narrow Marxism-oriented version, but a more general

10 More on this topic can also be found in biographical reflections such as the memoirs of the historian Aron Gurevich mentioned at the beginning of the article. 
"classic" 19th-century historism in its "Golden Age" form. However, at the same time Lotman surpasses such traditional historism. On the one hand, he still sees the merits of speaking about history and recognizes its important role - he even constantly continues to use such terms as "historical science"11 (Lotman 1996:301), but, on the other hand, Lotman's textocentrism, which is sometimes quite extreme, and his extensive attention towards the sphere of narrative devices, as well as the overall structure of historical text, appear to come rather close to what in Western historiography is usually referred to as 'the linguistic turn'. Clearly, Lotman is not as radical as Hayden White, Frank Ankersmit and the rest. In essence, though, Lotman grasps the core problem and, at the same time, the challenge of historiography in a similar fashion. What is even more remarkable is that all these advances in understanding are made in the context of the quite isolated Soviet humanities, and a step ahead of professional historians working in Soviet academic institutions.

\section{Boris Uspensky}

When writing on topics related to history and historiography, Lotman mentioned on numerous occasions that his ideas on these problems developed a lot because of his extensive discussions with Boris Uspensky. Besides being a close friend of Lotman, Uspensky was also one of his most recurrent co-authors, while, in terms of independent works and articles dedicated to the topic of history, Uspensky was probably even ahead of Lotman.

Among those numerous works by Uspensky, the first volume of his Selected Writings titled Semiotics of History. Semiotics of Culture [Semiotika istorii. Semiotika kul'tury, Uspensky 1996] stands out. Most of the works collected in the volume are dedicated to various empirical case studies of Rus' and Russian history, but some of them are more general and tend to touch important questions associated with the theory and philosophy of history.

In a chapter bearing the rather provocative title Historia sub specie semioticae ${ }^{12}$ starting from the very first paragraph Uspensky suggests that the historical process can be represented as a "process of communication" (protsess kommunikatsii) with some sort of language serving as a code. When it comes to the perception of one or another fact, either real or potentially possible, this language plays a very important role

11 Although to be fair, here it is difficult to say to what extent such term use is a matter of Russian language practice of the term "science" (nauka) use or Tartu-Moscow School's (and Lotman's) agenda to "scientify" humanities.

12 Originally the work was presented at All-Soviet-Union Symposium on Secondary Sign Systems (Tartu, 1974) and published in the symposium proceedings, but as a separate article it appeared couple years later in Культурное наследие Древней Руси (Uspensky 1976) 
(Uspensky 1996: 71). For Uspensky “[...] text of events is read by society"13. And if for Lotman it was narrativization of events that gave some structural unity and eventually organization to the historical material, Uspensky puts a particular emphasis on language as a force responsible for the organization of information: it is language that causes the selection of facts and eventually links them together. So in the end, it is this language in the meaning of code (or, better, the various languages) that become responsible for variable interpretations of the objective facts that are components of a text of events (Uspensky 1996: 72). In rough outline, the scheme could look as follows - different (in space/time) societies with different languages arrive at different interpretations and ascriptions of value to the fact or set of facts.

Another milestone work by Boris Uspensky, History and Semiotics (Perception of Time as a Semiotic Problem) [Istoriya i Semiotika (Vospriyatiye vremeni kak semioticheskaya problema), Uspensky 1988, 1989], chronologically appeared more than a decade later, yet in a way it could be regarded as a continuation of "Historia sub specie semioticae". Here, after twelve years, Uspensky repeats his own key ideas about the culturalsemiotic approach (kul'turno-semioticheskiy podhod) to history based on the model of communication, but this time the Moscow scholar also acknowledges the possibilities of other models and interpretations of history. He directly states that various interpretations do not cancel one another out, but, on the contrary, complement one another, and in a way reflect the complexity of the historical process (Uspensky 1988: 66).

Uspensky also dedicates an essential part of the article to proposing arguments in support of the idea that "History is semiotic in its nature [...] it involves a certain semiotization of reality - transformation of non-sign into sign and non-history into history"14 (Uspensky 1988: 69; my translation, T.B.). For him the "unfolding" of events in time implies language (semiotika yazyka), while the perception of history implies sign (semiotika znaka). Together, such a combination, along with conditions of temporal sequence and cause-and-effect relations, ensures semiosis of history (Uspensky 1988: 69).

Surprisingly, Uspensky's point about the semiotization of history was picked up by the Italian historian Luisa Passerini (Passerini 1999). She basically tried to bridge the viewpoint on history as a process of communication proposed by Uspensky with the contemporary - i.e. the late 1990s - state of affairs in Western historiography. In Passerini's opinion the semiotization of history opposes the prevailing structuralist definition of history, in which history was reduced to "a pulverization of infinitesimal events, to which only the subjective choices of the historian intervened to give some sense" (Passerini 1999: 14). To counter this, the Italian scholar suggests following Uspensky in conceiving the plurality and discontinuity of history as a process of communication.

13 [“...текст событий читается социумом”].

14 [“История по своей природе семиотична... она предполагает определенную семиотизацию действительности - превращение не-знака в знак, не-истории в историю”] 
Such an interpretation and, in some sense, adaptation of Uspensky deserves special attention, because, while in the late 1980s-early 1990s both Lotman and Uspensky were heavily influenced by nouvelle histoire ${ }^{15}$, that was at that point of time trendy in the Soviet Union, the semiotics of history (as part of semiotics of culture), at least according to Passerini, can be viewed also as important, and rather novel step forward that today's historians should take in order to assume their role on the cultural scene of the present (Passerini 1999: 19).

\section{Some conclusions}

If we look retrospectively at the agenda of the Tartu-Moscow School's semiotics of culture, alongside with the School's programmatic texts, e.g., the 1973 Theses on Semiotic Study of Cultures, it might leave the impression of an overwhelming academic optimism and, in a way, a story of the naïve belief in the possibility of revolutionizing humanitarian knowledge and rendering it scientific, at least on some level. Yet on the other hand, it is exactly this type of agenda and scholarly passion that brought fame to the TartuMoscow School, thereby allowing their somewhat tricky navigation throughout the Soviet humanitarian milieu. And perhaps this entire realm of approaching the past with all the questions about history, historiographical strategies, the essence of the historians' craft, and like problems serves as the best example of how academic opposition in a highly conservative environment can conceptualize and formulate new approaches, especially ones focusing on some universal tendencies.

The path which the members of the Tartu-Moscow School followed in their interest in history and historiography deserves to become a chapter in a textbook on the history of the Tartu-Moscow School. In the 1960s and early 1970s history was mainly a pure tool for many scholars in Tartu and Moscow. Historical investigations were a necessary element of the quality case study, simply because it was (and for a good researcher it still is) impossible to study for example the works of Alexander Radishchev without knowing the historical context of the time when those works were written, or to make any attempts to explain the Russian iconographic tradition without an in-depth knowledge of the history of the Orthodox church, etc. Thus during this "early" period of the School, the interest in history for Lotman, Uspensky, and others was primarily revolving around rather trivial positive knowledge that one or another historical investigation

15 In Universe of the Mind Lotman on numerous occasions gives examples from the Annales School (usually calling it nouvelle histoire) and even debates with Marc Bloch. In the articles mentioned above, Uspensky does not make any direct references to the Annales, but the reader can easily feel that he is relying on some of their ideas or at least takes into consideration historiographical tendencies originating from the French school. 
had to offer as an end result. Eventually, however, the spectrum of scholarly interests considerably broadened. History and historiography, both as very important elements in production of culture, became an object of attention on their own. Perhaps this whole shift can be associated with the blooming - at least at that point in time - project of the semiotics of culture that had a lot to do with the desire to embrace the totality of all the cultural processes. Thus, attention to historiographical practices was an obvious field to look into. As a result, already in the early 1970s it was possible to register the first attempts to approach history and historical writing from the standpoint of semiotics Vladimir Toporov started with some relatively straightforward questions and a couple of preliminary provisions, which, as he thought, in some sense equated history with the other secondary modelling systems.

A few years later, another Moscow scholar Boris Uspensky continued the discussion with his seminal and well-known paper "Historia sub specie semioticae". Uspensky's rather promising observation about a communication model which almost perfectly fitted to describe history/historiography is very appealing and definitely exemplifies the way of thinking of many prominent members of the Tartu-Moscow School. Modelling history as a communication process presupposed the presence of some senders, receivers, languages, codes, messages and other necessary elements accompanying any type of communication. Next entered Juri Lotman, who step by step tried to show all the traps and pitfalls that historians have to pass when attempting to investigate all the numerous nuances of these "processes of communication" between the past(s) and the present(s).

What was important for the scholars coming from the Tartu-Moscow School is that the presence of senders (e.g. ancient historians, chroniclers) and receivers (e.g. contemporary historians) almost inevitably presupposes various personal biases and difficulties in comparability between languages in a broad semiotic sense of the term; text presupposes code variability and (mis)interpretation; narrativization brings some particular type of descriptions, etc. Suddenly, the entire historiographical field appeared in a totally different light, and during the 1970s and 1980s on many occasions the Tartu-Moscow School was directly contradicting the views prevailing among the Soviet professional historians. For instance, Soviet historians hardly were free to examine or even comment on hyperbolizations, idealizations, ideologizations of the one and the only "correct" version of history propagated in the USSR. Or else, they rather comically, at least as regards the outcomes, tried to employ simplified 20th-century schemata in their interpretation of events and actions which had occurred centuries earlier. Lotman, on the other hand, specifically warned against the latter, and suggested recognizing and paying particular attention to the former. This is just one example that demonstrates a clear dividing line between the ideas of the Tartu-Moscow School and accepted theoretization of historiographical practices in the USSR. All in all, there is a whole corpus of works by the members of the Tartu-Moscow School which not only try to 
introduce new approaches to history and the historical (which was crucially important in the context of the almost totally isolated field of the Soviet historical science), but also optimistically propose solutions to many questions which were for the most part disregarded by professional historians.

\section{References}

Boyko, Taras 2014. Tartu-Moscow School of semiotics and history. Historein 14(2): 61-70.

Gasparov, Mikhail 1996. Lotman i marksizm. Novoye literaturnoye obozreniye 19: 7-13. [Гаспаров, Михаил 1996. Лотман и марксизм. Новое литературное обозрение, № 19: 7-13].

Gurevich, Aron 2004. Istoriya Istorika. Moskva: ROSSPEN [Гуревич, Арон 2004. История историка. Москва: РОССПЭН.]

Ivanov, Vyacheslav; Lotman, Juri; Piatigorsky, Alexander; Toporov, Vladimir; Uspensky, Boris 1973. Tezisy k semioticheskomu izucheniyu kul'tur (v primenenii k slavyanskim tekstam). In: Mayenowa, M. R. (ed.), Semiotyka i struktura tekstu: Studia poświęcone VII Międzynarodowemu kongresowi slawistów. Warszawa, Wrocław etc.: Ossolineum, 9-32. [Иванов, Вяч. Вс., Лотман, Ю.М, Пятигорский, А. М., Топоров, В. Н., Успенский, Б. А. 1973. Тезисы к семиотическому изучению культур (в применении к славянским текстам). In: Mayenowa, M. R. (ed.), Semiotyka i struktura tekstu: Studia poświęcone VII Międzynarodowemu kongresowi slawistów. Warszawa, Wrocław etc.: Ossolineum, 9-32.]

Lotman, Juri 1982. Redaktsionnoye primechaniye k stat'ye «Novyye metodiki statisticheskogo analiza narrativno-tsifrovogo materiala drevney istorii». Sign Systems Studies 15: 4448. [Лотман, Юрий 1982. Редакционное примечание к статье «Новые методики статистического анализа нарративно-цифрового материала древней истории». Труды по знаковым системам 15: 44-48.]

- 1990. Universe of the Mind: A Semiotic Theory of Culture. [Shukman, Ann, trans.; Eco, Umberto, intr.] London \& New York: I. B. Tauris.

- 1996. Vnutri myslyashchikh mirov. Chelovek-tekst-semiosfera-istoriya. Moscow: Yazyki russkoj kul'tury [Лотман, Юрий 1996. Внутри мыслящих миров. Человек-текст-семиосфераистория. Москва: Языки русской культуры.]

Passerini, Luisa 1999. History and semiotics. Historein 1: 13-20.

Postnikov, Mikhail; Fomenko, Anatolij 1982. Novyye metodiki statisticheskogo analiza narrativnotsifrovogo materiala drevney istorii. Sign Systems Studies 15: 24-43. [Постников, Михаил; Фоменко, Анатолий 1982. Новые методики статистического анализа нарративноцифрового материала древней истории. Труды по знаковым системам 15: 24-43.]

Toporov, Vladimir 1973. O kosmologicheskih istochnikah ranneistoricheskih opisanij. Sign Systems Studies 6: 106-150. [Топоров, Владимир 1973. О космологических источниках раннеисторических описаний. Труды по знаковым системам 6: 106-150.]

Uspensky, Boris 1976. Historia sub specie semioticae. In: Kul'turnoye naslediye Drevney Rusi (Istoki. Stanovleniye. Traditsii). Moscow: Nauka, 286-292. [Успенский, Борис 1976. Historia sub specie semioticae. Культурное наследие Древней Руси (Истоки. Становление. Традииии). Москва: Наука, 286-292.] 
- 1988. Istoriya i semiotika (Vospriyatiye vremeni kak semioticheskaya problema). Stat'ya pervaya. Sign Systems Studies 22: 66-84. [Успенский, Борис 1988. История и семиотика (Восприятие времени как семиотическая проблема). Статья первая. Труды по знаковым системам 22: 66-84.]

- 1989. Istoriya i semiotika (Vospriyatiye vremeni kak semioticheskaya problema). Stat'ya vtoraya. Sign Systems Studies 23: 18-38. [Успенский, Борис 1989. История и семиотика (Восприятие времени как семиотическая проблема). Статья вторая. Труды по знаковым системам 23: 18-38.]

- 1996. Semiotika istorii. Semiotika kul'tury. Izbrannyye trudy. T.1. Moscow: Gnozis. [Успенский, Борис 1996. Семиотика истории. Семиотика культуры. Избранные труды, Т.1. Москва: Гнозис.]

\section{Описывая прошлое: история, историография и ремесло историка в работах Тартуско-Московской школы}

В статье приводится обзор ключевых работ представителей Тартуско-Московской школы (Юрия Михайловича Лотмана, Бориса Андреевича Успенского и Владимира Николаевича Топорова) на тему истории, подходов к изучению прошлого, историографических стратегий, основ ремесла историка и т.д. Невзирая на факт, что данного рода тематики во многом оставались на маргиналиях научных интересов школы, ее представители все же высказывали множество интересных идей и предложений относительно проблемы истории и ремесла историков, тем самым обращая внимание на прежде не обсуждавшиеся вопросы и, в некоторой мере, служив катализатором новых научных дискуссий. Цель данной статьи - представить короткий обзор наиболее важных и основополагающих идей этого направления научных интересов представителей Тартуско-Московской школы.

\section{Mineviku kirjeldamine: Tartu-Moskva koolkonna mõtted ajaloost, ajalookirjutusest ja ajaloolase oskustest}

Artiklis antakse ülevaade Tartu-Moskva koolkonna esindajate Juri Lotmani, Boris Uspenski ja Vladimir Toporovi mõnedest olulistest teostest, mis temaatiliselt keskenduvad ajaloole, mineviku käsitlemisele, ajalookirjutuse strateegiatele, ajaloolase oskuste olemusele jne. Kuigi ajaloo probleemiga seonduvad teemad jäid Tartu-Moskva koolkonna uurimishuvides enamasti marginaalseks, väljendasid mitmed koolkonnaga seostatavad teadlased siiski uudseid ja huvitavaid mõtteid ajaloo ja ajaloolaste oskuste osas, tegid sellesisulisi ettepanekuid, ning teatud määral käivitasid isegi uusi diskussioone ja tõid välja seni tähelepanuta jäänud uurimisküsimusi. Käesolevas artiklis püütase anda lühiülevaade kõige olulisematest ning mõjukamatest TartuMoskva koolkonna teadlaste töödes leiduvatest ideedest nendel teemadel. 